\title{
Interactive Learning Media Development Using Software AutoPay Media Studio on Materials of Integration Techniques
}

\author{
Umy Zahroh \\ Mathematics Education Department \\ State Islamic Institute (IAIN) of Tulungagung \\ Tulungagung, East Java, Indonesia \\ umyzahroh@gmail.com
}

\author{
Muniri \\ Mathematics Education Department \\ State Islamic Institute (IAIN) of Tulungagung \\ Tulungagung, East Java, Indonesia \\ Muniri_t@yahoo.com
}

\begin{abstract}
This research is a developmental research based on the modified model of Plomp, that is: initial phase; design phase; phase of realization; test phase, evaluation, and revision. This development aims to produce interactive learning media that can assist students in understanding the concept of integration techniques that are valid, effective, and practical. Interactive learning media generated is in the form of autorun application programs that can work directly on a computer or laptop without having to install.
\end{abstract}

Keywords-learning media; autoplay media studio; Integral.

\section{INTRODUCTION}

The concept of integration techniques is very interesting to discuss because the majority of students who have taken integral calculus courses still have difficulty in solving integral exercises that are not simple. This is in accordance with the results of the subject matter preference test of differential equations. Based on the test results are still found a lot of students who have not mastered the concept of integral, and some have not been able to solve the integral exercises very simple. This fact is also reinforced by the results of Asyhar and Asmarani research that at the time of taking the course of differential equations, the majority of students have difficulties in understanding the concept and to determine the solution, especially when faced with the prerequisite materials, namely derivative and integral concepts. Students tend to forget the prerequisite materials and how to solve them[1]

The integral concept is the subject matter of Integral Calculus[2]. This course is a compulsory subject given to undergraduate students (S1) Mathematics or Mathematics Education. It is the student's duty to master and understand the material. Mastery of integral concept is one of the prerequisite material that must be possessed by students before taking the course of differential equations. If the student has not or has not understood the concept of integral, especially the material of integration techniques, then the student will experience obstacles in understanding the concept of differential equations.

Integral calculus is one of the prerequisite courses of differential equations that must be taken by students and graduated. If the student has not taken or gone but has not graduated, then the student according to the applicable academic rules may not take the course of differential equations. This is feared will hamper his understanding during the learning process takes place. While from the material aspect, the students are not only required to go and graduate, but the students are required to master and master the concept of integration techniques well. The hope is that when faced with differential equations problems demanding the mastery of the concept of integration techniques, the student is not in trouble.

Thus the importance of the ability or mastery of this integral concept so that all of us especially the lecturers are required to give more than enough attention so that the integral concepts, especially the integration techniques are taught seriously in accordance with the applicable curriculum. Lecturers can use appropriate instructional media and can theoretically support the mastery of integral concepts[3]. This needs to be done so that students do not experience difficulties when taking courses that require mastery of the concept of integral.

According to Arjaka, the use of computers as a media in learning has its own advantages that are not owned by other media, for example the computer can provide repetitive service, featuring dish in attractive format and design, animated figure and sound good, and serve individual differences[4]. This suggests that through dynamic learning media such as computers, students are empowered to study the material in accordance with the capabilities of each individual, observing patterns (with visualization), and can learn independently[5][6]. With the learning media, students can learn easily and practically without having to use paper sheets.

Learning the concept of integration techniques that emphasize mastery of basic concepts can be taught integral with computer assisted learning that can be adapted to the ability and choice of each student and can increase student independence in learning. Computers provide quick response when interacting with students, so that students personally feel valued and not bored. In addition, based on the results of research, that the computer is also one of the learning media that can positively influence in improving learning outcomes[7][8][9].

Based on the description, the researcher intends to carry out development research with the title of development of interactive learning media using autoplay software media studio on materials of integration techniques. 


\section{METHOD}

This research is a development research. The development of teaching materials uses educational problem-solving steps developed by Plomp (2013). The overall development phase of the teaching materials includes five phases, namely (1) the initial investigative phase, (2) the design phase, (3) the realization phase, (4) the evaluation and revision test phase, and (5) the implementation phase[10]. This study of learning media development modifies the development model of Plomp which initially has five phases into 4 phases, from the first phase until the fourth phase only. This is due to the limited time and material so that this research stops at the test, evaluation and revision phase.

The trial of interactive learning media on integration techniques was conducted on 44 semester 3 students, Mathematics Education Department, Faculty of Teacher Training and Education, State Islamic Institute (IAIN) of Tulungagung, academic year 2017/2018.

Data obtained from the validation and experiment of interactive learning media materials of integration techniques in the form of quantitative and qualitative data. Quantitative data in the form of scoring sheet validation of learning media by validator and student response questionnaire. Qualitative data in the form of responses, criticisms, and suggestions from validators during the validation process and students during the product trial process.

The data collection instruments for the test of validity, effectiveness and practicability mentioned above are in the form of questionnaires. Questionnaires used in this study form a checklist with a scale of $1,2,3$, and 4 . The criteria of each assessment scale used is as follows: number 4 means very good / strongly agree, the number 3 means good / agree, the number 2 means good enough / less agree, number 1 means less good / disagree.

\section{RESULTS AND DISCUSSION}

\section{A. The Results of Product Development}

This section will discuss about the development of interactive learning media using software autoplay media studio material integration techniques. Learning media produced in the form of computer-based learning media with the type of branching tutorial (branching tutorial). This media can be run on Windows XP, Windows 7, Windows Vista, Windows 8, or Windows 10 operating system. The menu system used in this media is a menu and submenu combination with animated view, and application menu can be selected using mouse. The complete media is described as follows.

\section{1) Front page.}

This page is a Splash Screen media page or a preliminary page before entering the main page. This page is about welcome greetings to these interactive media users. It also contains an animated media loading process with the content of the message to wait a while. Consider the following fig. 1 .

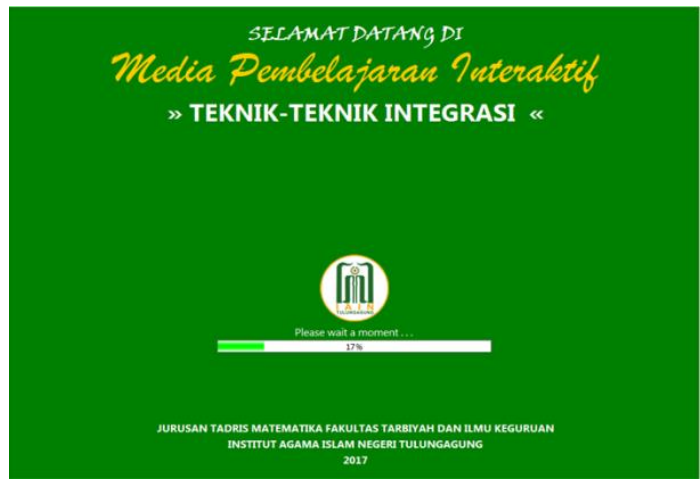

Fig. 1. Display of Media Splash Screen

2) Main page.

This page contains the basic menu before entering the media application. The menu includes: about the product, instructions for use, running the app, on / off music, and exit. Consider the following fig. 2 .

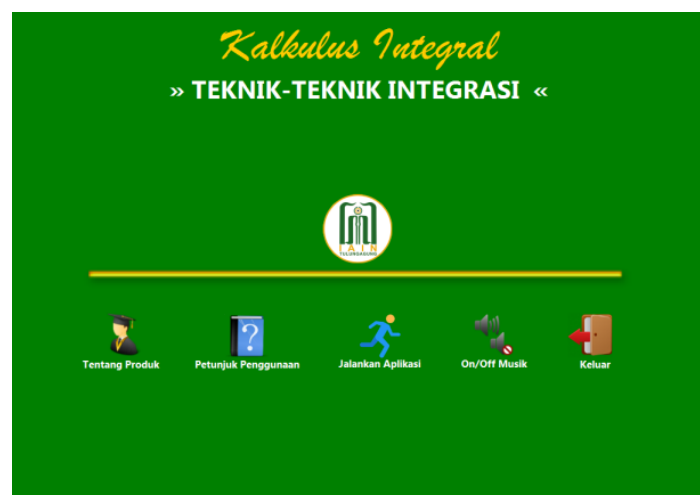

Fig. 2. Display of Main Page

3) Page of Product.

This page contains information about developed instructional media descriptions and their development team. Consider the following fig. 3 .

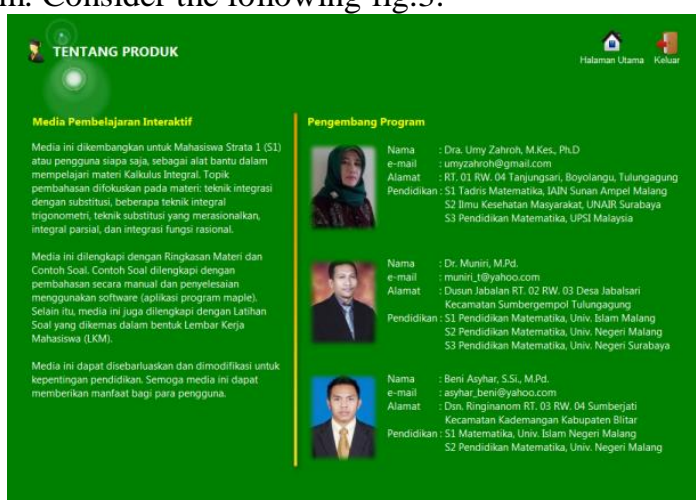

Fig. 3. Display of Product

\section{4) Pages of Instructions}

This page contains instructions on how to operate this learning media. The instructions include instructions for 
use on the main page and the application page. Consider the following fig. 4 .

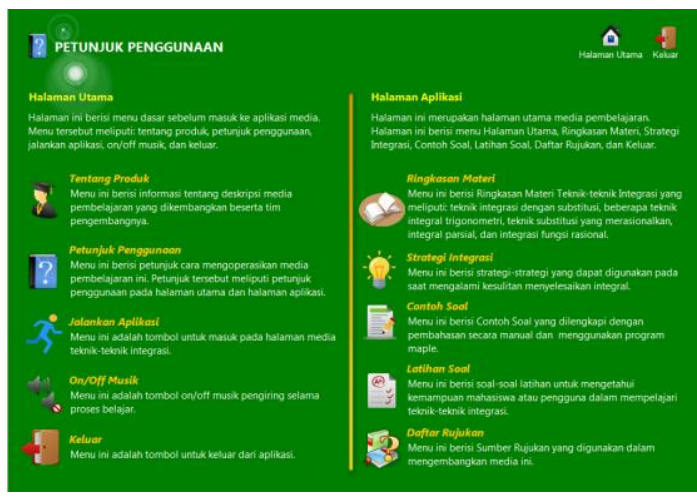

Fig. 4. Display of Media Instructions

5) Page of Media Application.

This page is the main page of instructional media. this page contains the main page menu (home), material summary, integration strategy, sample questions, exercise questions, referral lists, and exit. Consider the following fig. 5 .

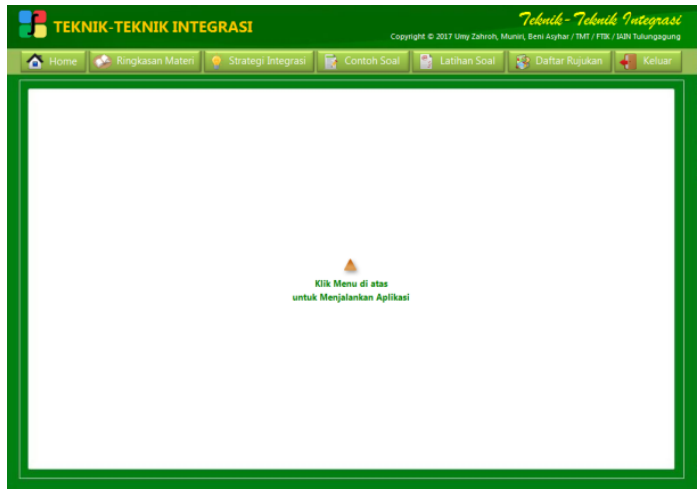

Fig. 5. Display of Media Application

\section{6) Material Summary Menu.}

This menu contains a Summary of Material Integration Techniques which include: integration with substitution techniques, some trigonometric integral techniques, rationalizing substitution techniques, partial integrals, and the integration of rational functions. Consider the following fig. 6 .

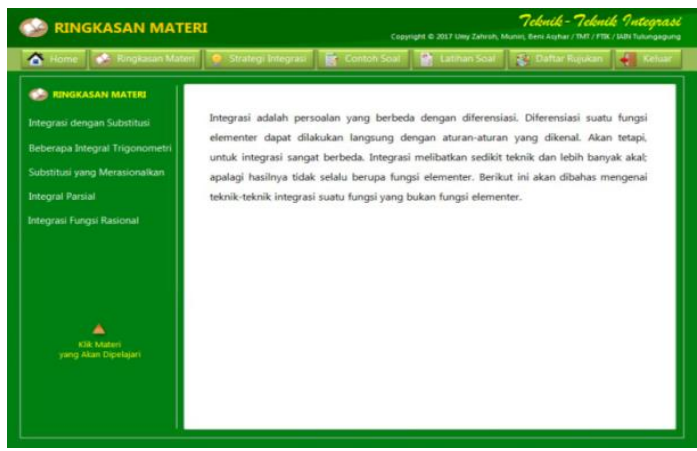

Fig. 6. Display of Material Summary Menu
7) Integration Strategy Menu.

This menu contains strategies that can be used when having difficulty completing an integral. Note the following fig. 7 .

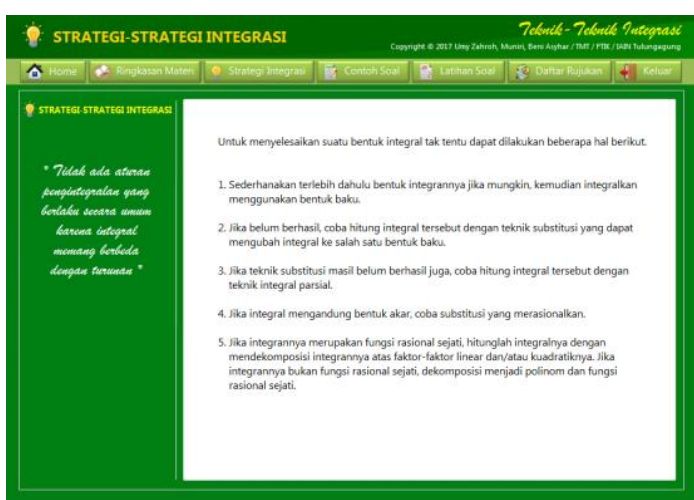

Fig. 7. Display of Integration Strategy Menu

8) Exercises Sample Menu.

This menu contains exercise sample that is completed with manual discussion and maple programming. Consider the following fig. $8 \mathrm{a}$. and Fig. $8 \mathrm{~b}$.

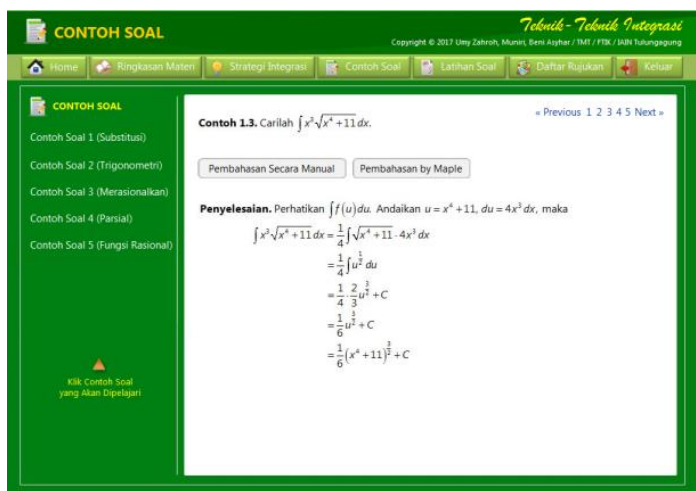

Fig. 8a. Display Menu Sample Exercise and Manual Discussion

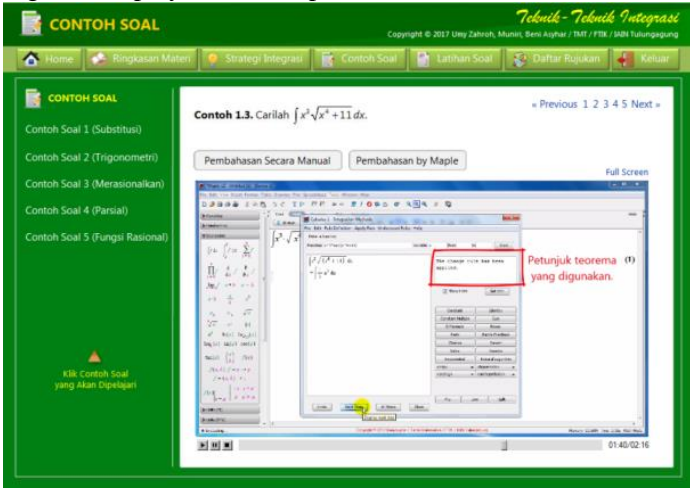

Fig. 8b. Display Menu Sample Exercise and Discussion Using the Maple Program

9) Exercises Menu.

This menu contains exercise questions to determine the ability of students or users in learning integration techniques. Consider the following fig. 9. 


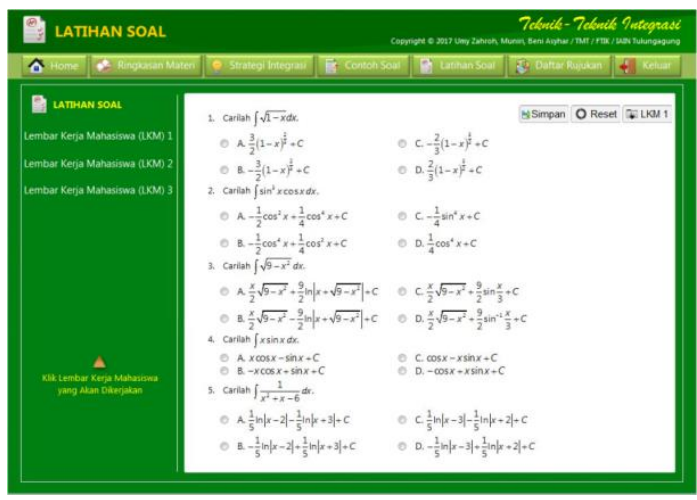

Fig. 9. Display the Exercise Menu

10) References List Menu. This menu contains the Referral Resources used in developing this media. Consider the following fig. 10.

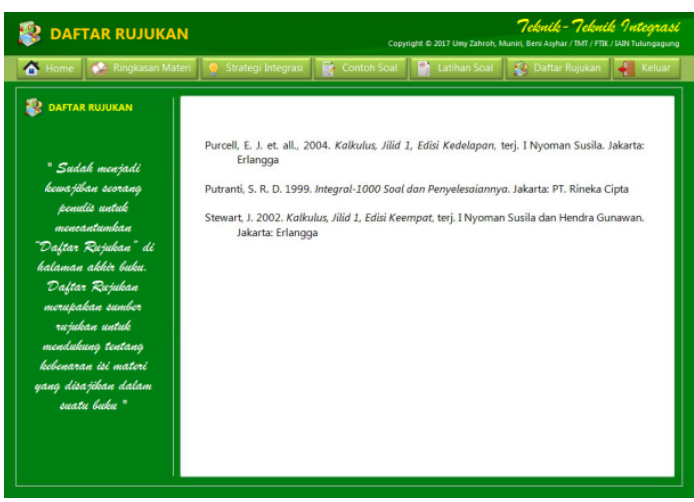

Fig.10. Display Menu References List

\section{B. Results of Product Validation}

\section{1) Results of Media Expert Validation}

Based on 4 aspects of the assessment, the aspects of graphic design, quality and menu function, media efficiency, physical quality with 12 grains assessment, obtained a total score of 44 with an average validation score of 3.67. This shows that according to validation score 3.67 is in valid category without having to do revision. That is, Interactive Learning Media on Materials Integration Techniques have been feasible used to test the product to users (students). In addition to quantitative data, qualitative data is also obtained from expert media validator, which is a suggestion that the media developed can also be operated in mobile. According to the validator, by developing android-based media easier for students in learning without having to turn on a laptop or computer. In addition, the validator also suggested that tutorial discussion of problems using maple program is given a vote.

Taking into account the suggestion of a media expert's validator, the researcher revises the product even if the validated media is valid. Researchers revise the video tutorials that exist in the media, the tutorial solving the example problem using maple program. Initially, the video only had text animation guide completing the integral problem using a maple program. Once revised, the video comes with text and sounds that guide integral problem solving using maple program.
While the suggestion that the media developed can be operated in mobile cannot be done by researchers because of program limitations. The output of the software used to develop such media is limited to computers only.

\section{2) Results of Content Expert Validation}

Based on 4 aspects of the assessment, the material or content aspects, language, presentation and appearance, and learning with 15 points of assessment, obtained a total score of 54 with an average validation score of 3.6. This shows that according to validation score 3.6 is in valid category without having to do revision. That is, Interactive Learning Media on Materials Integration Techniques have been feasible used to test the product to users (students). In addition to quantitative data, qualitative data is also obtained from expert media validators, namely in the form of improvement suggestions about writing. According to the validator, there are some text or formulas that are typos.

Taking into account the suggestion of a material or content expert validator, the researcher revises the product related to typing errors. This is done in order to avoid mistakes in understanding the concepts, theorems, and symbols that exist in the media. Associated with the decrease of partial integral formulas, researchers wrote $\int u(x) \cdot v^{\prime}(x)$ without $\mathrm{dx}$. An integral will have a meaning if it is written $\int \ldots d \ldots$ meaning, what function and what is integral to what variable. While the other typos do not reduce the meaning of certain concepts, it's just that there is something unnatural between the steps of problem solving.

\section{3) Results of Practitioneror Integral Kalkulus LecturerValidation}

Based on 4 aspects of the assessment, ie materials or content, language, presentation and appearance, and learning with 22 points of assessment, obtained a total score of 81 with an average validation score of 3.68. This indicates that according to validation score 3.68 is in valid category without having to do revision. That is, Interactive Learning Media Material Integration Techniques have been feasible used to test the product to users (students). In addition to quantitative data, qualitative data are also obtained from expert media validators, namely in the form of suggestions improvements on writing, as well as suggestions improved from the expert material writer. In addition to typographical errors, the practitioner's validator suggests displaying the correct answer option on student working Sheet 1 (2) which is done using Pythagoras similarity, ie according to the practitioner's validator, the problem can be solved by a substitution method or changing the integrity form in order to use Pythagoras similarity, that is $\sin ^{2} x+\cos ^{2} x=1$. According to the practitioner's validator, the problem can be solved by substitution method or change the integrity form in order to use Pythagoras similarity, that is $\sin ^{2} x+\cos ^{2} x=1$.

Taking into account the practitioner's validator's suggestion, the researcher revised the product related to student 
sheet 1 number 2 . The researcher changed the correct answer choice $-\frac{1}{2} \cos ^{2} x+\frac{1}{4} \cos ^{4} x+C$ to the one that was originally $\frac{1}{4} \sin ^{4} x+C$. Then the answers $\frac{1}{4} \sin ^{4} x+C$ researcher make the deception answer to $-\frac{1}{4} \sin ^{4} x+C$ and $\frac{1}{4} \sin ^{4} x+C$.

By changing the correct answer to student sheet 2 number 2, it is expected that the user can use the substitution method for question number 1, some trigonometric integrals (Pythagoras similarity) for question 2, rationalize method for question number 3 , partial integral for question number 4 , and method of function rational for question number 5 .

Based on the prevalence level 3.67 from media experts, 3.6 from material experts, and 3.68 from practitioners, it can be concluded that interactive learning media material validation techniques are valid. Therefore, the developed media can be tested to the users (students).

\section{Product Trial: Level of Effectiveness and Practicality}

Activities undertaken before conducting product trials, researchers meet lecturers integral calculus courses, namely Risa Fitria, on September 5, 2017. Researchers expressed their desire to conduct product trials, namely interactive learning media materials integration techniques to students who teaching by him. Then the lecturer does not object and invite the researchers to carry out the test. Based on the results of discussions with him and students it was agreed that the trial will be conducted 3 times, ie on 12, 19, and 26 September 2017 in the lecture room D21 at $08.40-10.20$ WIB. In addition, the researchers told students to bring a laptop during the trial and for those who have not been invited to join a friend who brought a laptop.

The first trial was held on Wednesday, September 12, 2017 at the D21 lecture hall at $08.40-10.20$ WIB. The initial activity of the trial begins with a copy of media files in the form of autorun files, meaning that the file can be run without installing poses. After the process of transferring media files to each laptop, the researcher asks the students to run the application by clicking 2 times. For the process of opening or running the application file, all the students there is no difficulty.

This first experimental activity of the researcher asks students to study the material of substitution technique and some trigonometric integrals. Overall the process of running the application there are no students who have difficulty. Questions from students appear only in the discussion section of the sample problem using maple program. Students can not display the video. This is due to the laptop concerned does not support the existing video on the media. Windows Media Player on the laptop is not updated so that error when displaying video.

The process of studying substitution techniques and some trigonometric integrals lasts about 75 minutes. After studying the material using an interactive learning medium on integration techniques, the researcher provided a test sheet 1 to test the students' understanding after studying the techniques of integration of substitution methods and some trigonometric integrals. This test sheet 1 contains 2 integral questions with a duration of 20 minutes working time. Upon completion of the work, the researcher submits that the two technical trials are the same and will be held on September 19, 2017 with the same space and time.

The material studied in the second trial is a rationalizing substitution technique and a partial integral. The second trial was held on Wednesday, 19 September 2017 at the D21 lecture hall at $08.40-10.20 \mathrm{WIB}$. The second test activity is relatively faster because students already have autorun media files. In addition, there is the possibility of students already studying the media before the implementation of this second trial. Students only take about 60 minutes to learn rationalized substitution techniques and partial integral. Furthermore, the students were subjected to 2 test sheets consisting of 2 integral questions with a duration of 20 minutes working time. At the end of this second trial, the researcher did not submit the next technical, but the students already understand that the next week there will be a third trial with a laptop and so on.

The third trial was held on Wednesday, September 26, 2017 at the D21 lecture hall at $08.40-10.20$ WIB. The third material is the technique of integrating using rational function method. There are several types of rational functions encountered during the integration process. There is a true rational function and there is a rational function is not true. Just like the second test, the student takes about 60 minutes to learn the materials of integrating techniques with rational functions. Furthermore, students do the questions on the test sheet 3 which consists of 2 questions with a duration of workmanship of 20 minutes.

Based on data of experiment result of interactive learning media, the material of integration techniques is known that 43 students from a total of 44 students get an average score of more than 61 or $97.73 \%$. Only 1 student or $2.27 \%$ got an average score of less than 61 . This indicates that the student has finished in studying the material of integration techniques. Or in other words that the media developed effectively and can be used in classroom learning.

In addition to the quantitative data from the results of 3 tests, the qualitative data obtained from the test results and 3 test results is related to the level of student accuracy. Based on the results of 3 tests, errors that often appear is not careful in writing positive and negative signs that resulted in wrong results. In addition to the level of accuracy of students in working on the problem, students who do not have a computer or laptop is still difficult to operate the media. Those who do not have a computer or laptop usually learn together with their friends who have a computer or laptop.

Furthermore, to determine the level of practicality of the media developed practical test conducted by spreading the questionnaire of practicality to the students of the trial participants. The researcher selected 4 student representatives at random to provide an assessment of the quality of the media. Based on the assessment of 4 students on the quality of Interactive Learning Media on Materials Integration Techniques obtained a total score of 225 and the practical average of 3.31. This shows that according to the practical score score 3.31 is in the practical category without having to revise. 


\section{CONCLUSION}

Based on the validation results of the graphic design aspects, the quality and function of the menu, media efficiency, physical quality, material or content, language, presentation and appearance, and learning, developed media can be tested to the users after obtaining an assessment that the media is valid with a validity level of 3.67 from media experts, 3.6 from material experts, and 3.68 from practitioners. Then, the developed media is effective and can be used in classroom learning because based on the data of the test results it is known that 43 students from a total of 44 students get an average score of more than 61 or $97.73 \%$. Only 1 student or $2.27 \%$ got an average score of less than 61 . While from the practicality test, the media developed practically with the practical average of 3.31. Overall, interactive learning media on the material of integration techniques developed has been valid, effective, practical, and feasible to be used as an alternative media learning materials integration techniques.

The advantages of this media are: 1) Can be operated directly without having to do the installation process; 2) This media can be run on Windows XP, Windows 7, Windows Vista, Windows 8, or Windows 10 operating systems; 3) Equipped with menus and submenus on each page; 4) Sample problems presented manually and computation; 5) Solving the example problem using maple program equipped with guidance in the form of text and sound; 6) Provided companion music or companion learning process, this music can be turned on or off; and 7) This media has a small size (214 MB), so it does not require large storage space. While the weakness of this media are: 1) This media can only be studied, the results of the discussion of sample problems, either manually or using maple program can not be copied to another worksheet; 2) This media cannot be operated in mobile; 3) This media cannot be used to solve other integral problems.

\section{REFERENCES}

[1] B. Asyhar and D. Asmarani, "Mengatasi Kesuliatan Mahasiswa Tentang Materi Persamaan Deferensial Menggunakan Bimbingan Belajar Individual (Face to Face Relationship) Berbantuan Program Maple," J. Pendidik. Mat., 2016.

[2] E. J. Purcell, D. Varbeg, and S. E. Rigdon, Kalkulus, Jakarta: Erlangga, 2004

[3] Newby and Timothy, Instructional technology for teaching and learning. 2000.

[4] S. Arjaka, "Media Elektronik Berbasis Komputer," J. Media Seni dan Desain, pp. 1-10, 2012.

[5] Sehan and Derar, "The Effect of Graphing Calculator Use.," Int. J. Math. Teach. Learn., 2006.

6] Tiwari and T. Kumar, "Computer Graphics As An Instructional Aid In An Introductory Differential Calculus Course," Int. Electron. J. Math. Educ., 2007.

[7] Masduki and A. Nugroho, "Pembelajaran Matematika Dengan Media Berbasis Komputer Ditinjau Dari Aktivitas Belajar Siswa,”2011, pp. 159-164.

[8] Kintoko, I. Sujadi, and D. Sari, "Pengembangan Media Pembelajaran Matematika Berbantuan Komputer Dengan Lectora Authoring Tools Pada Materi Bangun Ruang Sisi Datar Kelas VIII SMP/MTS," $J$. Elektron. Pembelajaran Mat., 2015.

[9] I. D. Setyono, "Pengaruh Media Pembelajaran Berbasis Komputer Terhadap Prestasi Belajara Matematika Ditinjau Dari Keaktifan Belajar Siswa,” 2016, vol. 25, no. Knpmp I, pp. 261-271.
[10] T. Plomp, Educational Design Research Introduction, Enchede: SLO Nedherlands Institute for Curriculum Development, 2013. 